\title{
Chapter 3. Ritual Domains and Communal Land in the Highlands of Bali
}

\section{Thomas Reuter}

\section{Introduction}

The central highlands and some coastal areas of Bali are home to a little-known indigenous minority group, the Bali Aga or 'Mountain Balinese'. This paper focuses on ritual domains formed by clusters of Bali Aga 'villages' (desa adat or desa ulu apad). These regional, spatially bounded and historically conceived networks are known as banua. The banua and its constituent desa form a sacred landscape inscribed by the memory of a continuous history of human settlement and migration, and re-inscribed through origin narratives and ritual performances at sacred sites of origin, which are marked by shrines or temples. This multi-layered process of inscription defines how different groups of participants relate to the land in terms of spiritual ownership or obligation but also in terms of their practical ownership of land as a primary material resource.

I will argue that many agriculturalist peoples in the Austronesian world, such as the Bali Aga, define their social identities as well as rights of access to particular pieces of arable land by creating a hermeneutic circle of reciprocal mapping between social and physical landscapes. I further suggest that there is a historical movement of emphasis from material to symbolic resources as spatially defined entities grow in size or complexity. Because actual land rights tend to be negotiated locally, in the village or the 'house', the nature of people's claims to a relationship with an area of land tend to become more distant and detached from practical concerns with material resources in the much larger structure of a regional, ritual-political organisation such as the banua. At this level of social organisation, status and other forms of symbolic resources tend to become the primary concern instead. ${ }^{1}$

\section{Highland Bali and Comparative Austronesian Studies: Historical and Linguistic Considerations}

My ethnographic research has revealed a confluence of Austronesian and Indic influences in highland Balinese culture. Annual ceremonies at the regional temples, which form the ritual centres of banua, for example, contain some elements of classical Hindu religion alongside other important rites, such as buffalo sacrifices, which are more commonly associated with cultures of the Austronesian region of which Bali is a part. In short, the cultural history of the 
banua of the Balinese highlands is in many ways typical of societies in the Indian-influenced part of the Austronesian world.

Megalithic stone carvings and other archaeological evidence suggests that some major contemporary regional temples of highland Bali have been places of worship from prehistoric times (Bernet-Kempers 1991). The earliest Indic kingdom on Indonesian soil was established in Kutai (Borneo) in the fifth century AD and others soon after in Java and Sumatra, while Indian trade and cultural influence in the region, including Bali, probably dates back to the first century AD at least (Ardika and Bellwood 1991).

The earliest written sources of local cultural history are ninth-century royal edicts from the first Balinese Hindu kingdoms (negara), which might have been centred in the region of the highlands and northern coast. These edicts depict several important and ancient temples that are the ritual centres of contemporary banua already at the heart of regional ritual organisations (Reuter 2002a). The prehistoric significance of these same sacred sites makes it seem very likely that ritual domains preceded the formation of early Hindu kingdoms on Bali as well as providing an organisational platform for their establishment, not just in the highlands but on the island as a whole (for evidence of similar ritual networks with royal patronage in southern Bali, see MacRae, this volume). By the same token, there is no doubt that the evolution of highland domains took a new direction under the influence of local Hindu kingdoms and again after their collapse in the 14th century, when Javanese invaders established new Hindu dynasties centred in the south.

Bali Aga society provides an ideal contemporary vantage point from which to explore some of the Austronesian foundations of Balinese culture that have become less visible in the polities and communities of the southern lowlands (Reuter 2002a). Highland people actively resisted the influence of Javanese-descended royal courts of southern Bali and the orthodoxies of the Brahmana priesthood affiliated with these courts for more than half a millennium (Reuter 2003). Studies of Austronesian traditions in highland Bali and in Balinese culture generally are also exceptionally valuable to comparative Austronesian studies because they were and still are better protected under the umbrella of Hinduism, with its great tolerance of local diversity, than societies in other parts of Indonesia and beyond whose local religious practices and belief systems have been devalued and abandoned under the influence of proselytising, monotheistic world religions. ${ }^{2}$

Many societies in the Austronesian-speaking world show patterns of regional and local organisation wherein a category of 'place' - the kingdom, domain, village or house - serves as a key idiom of social identity in its own right, though often also in combination with a notion of common ancestry or 'name'. In the Balinese case, and probably in other societies too, there are recurrent metaphors, 
idioms and concepts in how the idea of 'place' is defined across different levels of social organisation. Indeed, the distinctions house-village, village-domain, and domain-kingdom are all more or less fluid (see Reuter 2002a). In part, this conceptual similarity and fluidity is a reflection of historical processes. A house with a cluster of branch houses could grow into a village, which in turn could acquire branch villages and grow into a domain, which could-alone or in conjunction with other, allied domains - become the ritual foundation for the formation of a Hindu polity. ${ }^{3}$

Of the four most important terms for territorial categories in Bali, 'desa', the term for village, and negara, the term for a kingdom or its capital town, are of Sanskrit origin while umah, 'house', and 'banua', the contemporary designation for a regional ritual domain, are Austronesian words. My main focus in this paper will be on the regional institution of the banua, given that regional forms of social organisation in the Austronesian world remain relatively under-explored. There is a large body of literature on the comparative ethnology of much smaller social forms, namely the 'house' ('rumaq, *balay, but occasionally also *banua) and there has also been much research and debate on very large institutions, such as the classical Indic polities of South-East Asia (kerajaan, negara). The comparative lack of studies on regional organisation is regrettable especially because it is rather difficult to imagine how states or large chiefdoms in the Austronesian world could have been built directly on a foundation of localised houses and in the complete absence of ritual alliances between houses within villages, domains, or other, similar social structures of intermediary size.

Any comparison of the social organisation of a number of Austronesian societies inevitably leads to the discovery that speakers of Austronesian languages use similar metaphors and related words to describe their ideas of and relationship to a particular stretch of land, even though the meaning and social implications of the reflexes may vary widely. In this case, reflexes of the Proto-Malayo-Polynesian reconstruction *banua in the contemporary languages of this language family all tend to convey the general idea of a 'place' of varying size, namely, the ancestral territory of a 'longhouse', 'hamlet', 'village' or 'domain'. For example, in Old Javanese, the term wanua connotes a 'village'; in Iban, menoa rumah is the 'territorial domain of a longhouse'; in Ngada (Sara-Sedu), a nua is a 'village' or 'ritual territory'; and in Lio, nua is a 'ritual territory, domain or polity'. Similarly, in Goodenough, manua connotes a 'village' or 'dwelling place', while in Vanuatu (East Ambai) and Fiji vanua, is a 'land' or 'territory'. More sporadically, reflexes of *banua are used to refer to (the territory of) a 'house', as in Toraja, Banggai, Wolio, Molima and Wusi-Mana. Two other sets of terms with a similar emphasis on 'place' in this group of languages include reflexes of the contructs *tanah (tana, tanaq, taneq, taneh, tano, 'ano), of which the Balinese reflex is tanah, and *daya (darat, dare, dae, rae, rai). 
Similarities and differences in the cultural meaning and social implications of these terms need to be established through detailed ethnographic and ethno-historical research, followed by ethnological comparison. This volume is dedicated to the task of an ethnological comparison of social categories based on the idea of a place or territory. As a contribution, this paper will unpack the meaning of the Balinese reflex banua by describing in some detail what a banua is or can be in the highlands of Bali.

\section{The Ritual Domains of Highland Bali}

Balinese communities at the time of the early royal edicts appear to have been organised around a council of seniority-ranked elders, who were paired and grouped into ceremonial moieties. This pattern of precedence-based village organisation is still a defining characteristic of contemporary Bali Aga communities (Reuter 2002b). The edicts refer to the localised communities represented by these elders as banua (Old Balinese) or wanua (Old Javanese), rather than desa. Most likely the meaning of the term banua in Bali at that time referred to something more like a 'village' than a 'domain'. It is possible that the newer term for village, desa, was introduced later in order to distinguish between a single village community and territory (desa) and a very old settlement (banua), which once had a very large 'territory' on which a whole cluster of newer hamlets were established as the population grew, naturally or by immigration. When these newer settlements became independent villages, the original village lost direct control over the land that fell within their respective 'village territories' but retained a special status as ritual overlords in the domain as a whole. In historical perspective, therefore, the term banua in Bali has consistently carried the meaning of 'a unit of land or territory shared by a community', while the size and complexity of the unit of land and community thereby designated appears to have changed over time in the direction of greater complexity. This trend is evident in the contemporary situation.

Bali's central highlands and northern coast today are home to about 100 Bali Aga villages. These villages form at least 13 distinct banua or 'ritual domains' of varying size, clustered around regionally important temples (pura). These ritual alliance clusters are depicted in Figure 1.

Each domain is a bounded space in that all of the villages within certain boundaries normally partake in the one encompassing ceremonial order. While domains are named after and are socially oriented to a centre, the boundaries, while not emphasised very much in ritual, are quite clear. This is because the participating villages have definite boundaries nowadays, and probably always did. The royal inscriptions of classical Bali already mention streams and ridges as village boundaries. In any case, banua networks, figuratively speaking, do not have any gaps or outliers. 
Figure 1: Ritual networks in the highlands of Bali

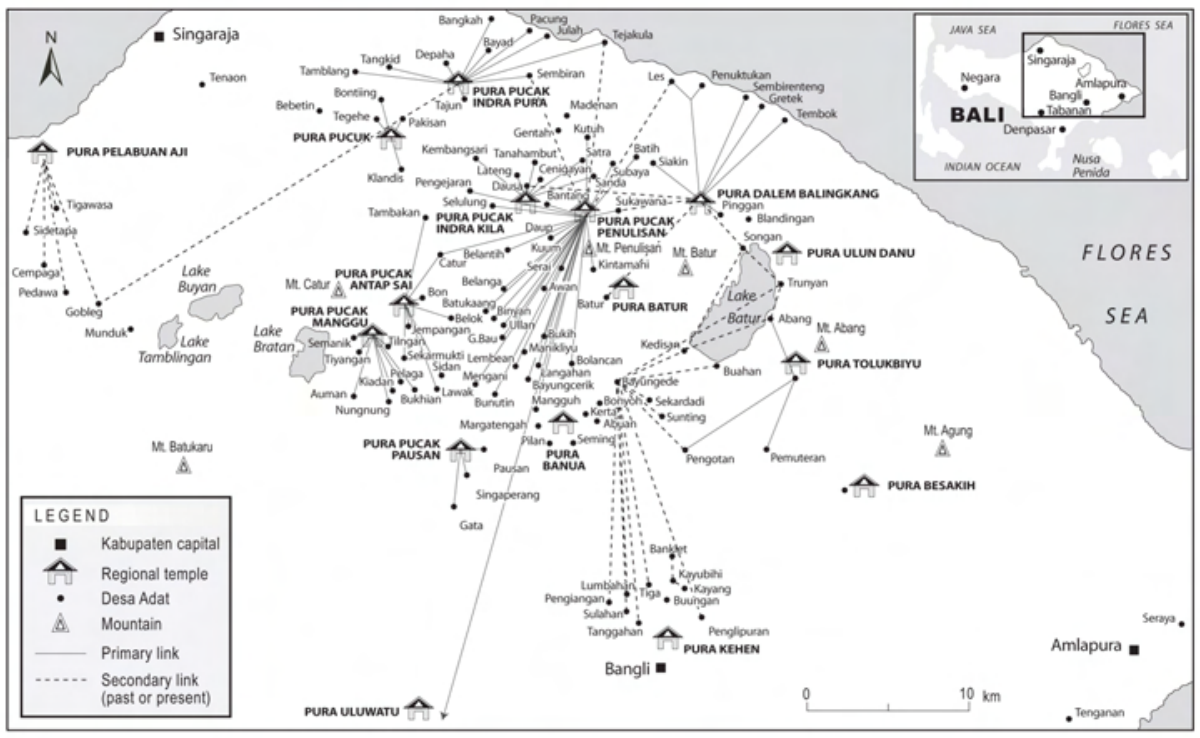

It is a common feature of most of the larger domains, however, that they incorporate smaller subsidiary domains, each with its own regional temple of lesser status. Such complex layered networks are nevertheless conceived as single banua with a common origin rather than overlapping, historically unrelated domains. There are a few cases where two distinct domains do share part of the same network of villages. However, this usually means that one of the two was formerly a sub-domain of the other, has attempted to break away from it to become an independent domain in its own right, and has had only partial success in doing so. 4

From the perspective of local participants, the term banua designates a bounded 'spiritual territory'. More specifically, a banua is conceived as a large and clearly defined area of agricultural land whose fertility, along with the prosperity (rahayu) of its human occupants, depends on the ancestral deities enshrined at the domain's paramount temple or pura banua. Likewise, the smaller divisions of land within a domain are under the protection of the lesser and more local ancestor deities of 'village temples' or pura desa. These lesser village deities are often identified in narratives of origin as the children or children-in-law of the domain's paramount founder deity. The congregation of a pura banua is thus a network of otherwise autonomous villages, just as the congregation of a pura desa is a group of otherwise autonomous households (umah, 'house', or kuren, 'hearth'). This raises the question of why these independent villages would find it desirable to continue to recognise the precedence status of the origin village. 
A banua is a self-evident fact to its participants; a paramount natural (sekala) and supernatural (niskala) reality with a social character. The force of this social reality is vested in the agency of post-human or non-human agents - the local ancestral and non-local Hindu deities. The relationship with ancestral and other deities is enacted dramatically in a ritual setting. A ritual domain is thus experienced in ritual as a given and is described officially as non-negotiable. Simultaneously, from an ethnographic perspective, the spiritual territory or domain of a temple is a socially constructed reality, a man-made and negotiated boundary and a set of internal relations inscribed on the land by the narrative and ritual performances of a temple's human congregation.

I would like to reconcile these two perspectives. Participants, speaking from a position of individual lived experience, are quite correct in their perception of the banua as a non-human facticity. First of all, the land itself is part of a self-evident material reality that predates human occupation, although land is also transformed by human beings for the purpose of agriculture or house-building; land is thereafter classified, respectively, as tanah ladang or tanah pakarangan. It is also self-evident that nearly all land is visibly occupied and claimed by someone - agricultural land by means of regular cultivation and the construction of garden huts and fences, and house land by means of regular habitation. Given that particular people will argue a claim to the right to occupy particular pieces of farm and house land, this land cannot easily be taken away from them. The banua and its subsidiary desa therefore are not only a material given, but also a 'supernatural' or rather 'post-human' facticity, in the sense that contemporary society is encountered as a reality that was created by now-deceased and invisible others in the past, namely, by one's own historical predecessors or 'ancestors'.

From the point of view of an interactionist social theory, this still may not seem like an entirely satisfying explanation of the status quo in a banua. Although a particular land tenure arrangement, once it has been established, may constitute a self-evident social fact, the more important questions are how such arrangements were established in the first place, and by what means they are maintained or changed. Indeed, local participants are immensely interested in the same questions, though their intuitive answers may be phrased in an unfamiliar idiom.

The Bali Aga are always keen to discuss how relationships between particular people and places came to be. Each domain has its origin narratives, and so does every village within it. Often enough, these narratives exist in different and competing versions. Ritual performances aimed at maintaining good relations with the 'supernatural', which are regular, frequent and elaborate in the highlands of Bali, serve to commemorate this origin history. As are the narratives that inform them, these rituals are subject to variation and can also become a 
means of contesting origin-based status claims. For the Bali Aga, the answer to the question of how a village or domain came to be in the hands of particular people is, 'history', and as for the means by which this claim to the land is maintained or challenged, the answer is 'commemorating [or forgetting] particular ideas about history in a ritual context'. If I am to convey accurately what a banua is or can be, my two principle tasks therefore are to do justice to the regulated practices by which the Bali Aga conceive of the present as a self-evident product of the past, while at the same time acknowledging that the present is also the not-so-self-evident product of a strategic remembering or reconstruction of the past.

Let me begin by looking at regulated practice. Usually, when it is not in (com-) motion, a banua 'rests', so to speak, on a shared conviction among participants that the founders of all the villages in the domain originated from a single source village, namely, the village where the domain's paramount temple is now located. Origin narratives retell how these founders left the source village, cleared land somewhere nearby to establish gardens and hamlets, and how these hamlets eventually became independent villages with their own local temples. In these temples, the branch village founders are now enshrined to be venerated by their many descendants. These deified founders still own the land because death is not the end of life, of rights and obligations, but simply the beginning of a gradual transformation from a human to a post-human state of being.

There are different degrees of post-humanisation or sacredness on a temporal scale of precedence. This means that the ancestral founders of a branch village, even though they are local deities in their own right, still have ritual obligations towards their own ancestors, who are enshrined in the origin temples of the domain's source village. (Their obligations in fact mirror those of members of a small kin group around a branch house temple towards the older, larger temple of their clan or local clan segment.) In practical reality, of course, the ritual obligations from junior to senior ancestors have to be met by the living descendants of the junior ancestors in the branch villages. As a consequence of this remembering of ancestral relations, the pura desa of the source village is transformed into a regional pura banua, which is thereafter maintained collectively from regular contributions (peturunan) paid by every household in every one of the branch villages.

Figure 2 depicts the logical pattern of these relationships in schematic form. The diagram is based loosely on the internal organisation of the very large banua of the regional temple Pura Pucak Penulisan, which has four major sub-domains centred on the temples of the ancient villages of Bantang, Selulung, Kintamani and Sukawana (Reuter 1998). Each of these secondary ritual centres has its own following of subsidiary villages. What the figure does not show and as we shall see later, the sub-domain of Kintamani, for example, contains yet another, smaller 
Figure 2: The path of origin and the ritual order of a domain (banua)
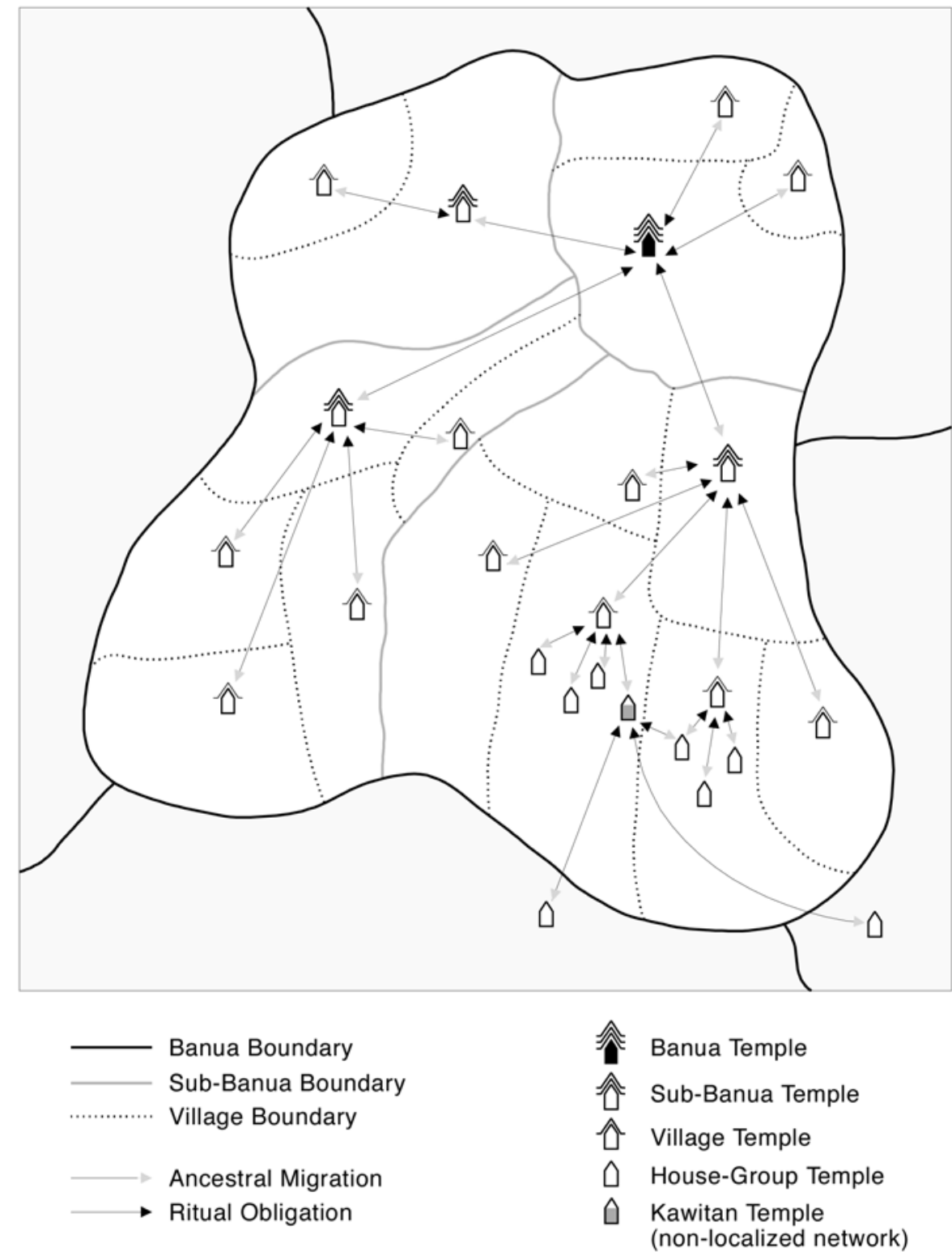

sub-domain consisting of a cluster of villages around the small regional temple Pura Tebenan. In short, the logic of the status relationship that gives an origin village ritual precedence over its branch villages can be applied recursively wherever people recognise an extended sequence of historical migrations and settlement foundation events. The length of such a historical sequence of 
migrations may seem unlimited theoretically, but in ritual practice connections of precedence are restricted within the more narrow confines of a socially recognised history. My research has shown that the depth of ancestral origin and migration connections in a domain usually amounts to only two layers (origin and branch), and rarely exceeds three layers, as depicted in Figure 2 (see Reuter 2002a). Four layers are very rare, and I have no example of a five-tiered domain. ${ }^{5}$ The pattern shown in Figure 2 may look much like a network of ancestor temples, and in some ways it is. However, what we are dealing with here is not a simple kinship system nor a complex one, but a Lévi-Straussian house society in a ritualised modality (see Reuter 2002b). The organising principle is a sequence of inhabited places represented symbolically by sacred ancestor houses or 'temples'. These sacred houses are ranked in order of their foundation. In short, the contemporary order of ritual obligations maps and retraces a path of origin through a socio-historically inscribed landscape.

The emphasis in this system of social relations lies on a series of place names within a landscape rather than on personal names in a genealogy. Villagers in the highlands are unable to recount a genealogy of named predecessors from themselves all the way back to either the clan or village founders, let alone the domain founders. People's genealogical memory usually spans no more than four generations, and rights to an inheritance as well as duties to ritually post-humanise recently deceased predecessors are serious issues only within that range. Beyond four generations, what serves as a means of connecting people within kin groups are once again links between sacred places, rather than named ancestors. The connections in this case are between older and newer ancestral 'origin temples' or sanggah kamulan, the private temples of groups of agnates whose individual houses are usually located within a single compound. The older temples in a sequence of source and branch sanggah become sanggah gede (great sanggah) and the oldest sanggah within a clan is elevated eventually to the status of a so-called pura kawitan ('temple of the source, beginning, or trunk' $^{\prime}{ }^{6}$ One reason for this reliance on place markers and forgetfulness of personal ancestor names was that despite their agnatic ideology and patrilocal residence, members of Balinese kin groups in fact often chose to incorporate male outsiders through uxurilocal marriages (nyentana) and strategic adoptions.

This openness of place-based categories is even more evident at a village or domain level. Villages may afford a special status to members of the houses of the founding emigrants who originated from an older source village. In most villages, however, there are also newcomer houses founded by more recent immigrants from elsewhere. At a domain level, flexibility about ancestry is manifest in the fact that sometimes entire villages are said to have been founded by immigrants who were not at all related to the source of the domain by descent. Their relationship to the source was established on the basis of their use of domain land, which incurred a ritual debt that had to be paid in accordance 
with the customs of the domain. In this way, newcomer settlements were culturally and ritually incorporated to such an extent that they soon became difficult to distinguish from genuine branch villages that were founded by emigrants from the source village (Reuter 1999).

On whatever level of organisation they may operate, models of human relations that are based on 'place' rather than 'name' have the advantage of greater inclusiveness, of being able to accommodate a diversity of people within its folds. This is all very well, but encounters with newcomers also need to be regulated. People will tend to protect their land and other resources from new claimants unless they have a good reason for sharing. This problem returns me to my second task, that is, to analyse processes of memorising and reconstructing the past which serve as a strategy for negotiating and contesting the distribution of land and other resources.

I will approach this analytical task first at the village level. The most important aspect of history to be either actively remembered or conveniently forgotten in this context is that certain people are the agnatic descendents of the village founders, or literally, 'the people of the trunk' (wedan), while others are not. This distinction is almost universally necessary given that village founders were nearly always joined by unrelated immigrants later on, by 'newcomers' or, literally, 'people of the leaf' (pendonan). In an agrarian society such newcomers required land and as long as vacant land was still available it was freely given. Indeed, newcomers were rather welcome because together with a share of land, they were also given a share of the fixed cost of celebrating the festivals of the village temples in honour of the founding ancestors and spiritual owner-caretakers of that land. In most highland villages, though not in all, land was thus given to the newcomers outright rather than being leased to them as dependent clients or sharecroppers.

In most cases, the botanic metaphor-based distinction of trunk and leaf people thus has limited significance when it comes to controlling access to land. While members of the villages founder group tended to have larger landholdings overall, newcomers had to be given villages land or sufficient other land to be able to make a living. The twofold social classification of wedan and pendonan is still very important, however, due to a distinction between two types of land, namely 'village land' (tanah ayahan desa) and 'owned land' (tanah milik). ${ }^{7}$ Only the men who farm classificatory village land are represented in the community's seniority-ranked council of elders and priest-leaders, while others are not. The council (ulu apad) consists of the male heads of eligible households and meets on new and full moons in the village longhouse. Divided into ceremonial moieties, the men sit in order of precedence (depending on when they became married householders) on the massive side beams of the longhouse floor, with the ranks 
decreasing from the tip (and uphill) to the trunk (downhill) end of the beam (compare with the nili ele councils of Seram, Boulan-Smit, this volume). ${ }^{8}$

Belonging to the people of the village trunk or an early, now fully integrated immigrant group that has been admitted into the village council thus signifies access to political and ritual authority. In short, material resources, in the form of land, were given away for two reasons: to share the material costs of ritual with others and to acquire symbolic resources in relation to these others. These symbolic resources take the form of ritual and political authority over a group of client households which are economically independent.

Contemporary banua have much less relevance for land usage rights than desa. A ritual domain is not at all definable as a landowning corporation, whereas a village can be, or at least formerly could be, classified as such. Prior to Indonesian independence, village land was often owned by residents collectively and in many cases individual plots of land were rotated continuously from recently defunct households of older, retired or widowed couples to the households of newly married couples, irrespective of any relationship by descent between them. After following a shift from subsistence agriculture to cash crops such as coffee, which require long-term labour investments, this rotation system was abandoned in many villages in favour of a de facto inheritance system, whereby the special character of 'communal land' became more and more nominal (see also Waelty 1993). In other villages all land has been classified as 'privately owned' for as long as anyone can remember, and is passed on by inheritance within kin groups. ${ }^{9}$ In both types of villages, the introduction of new legal codes by the Dutch and Indonesian governments has encouraged a shift to more modern notions of landownership, especially from the 1970s onwards. Nevertheless, there is no such thing as individual landownership free of ritual obligations in highland Bali.

There is evidence that the banua was still relevant for maintaining land claims until the 1930s and the desa has remained important until today. Occupants of classificatory village land can be dispossessed if they fail to meet their ritual responsibilities to the desa and, theoretically at least, to the banua of which it is a part. Individual ownership of so-called 'private land' (tanah milik pribadi) is also contingent on meeting ritual obligations towards the village (desa) or the hamlet (banjar), or both, as well as social obligations towards one's extended kin group (at least for as long as the older generation can delay a formal transfer of land certificates to their heirs). Even the non-resident owners of land used for commercial purposes are subject to a ritual levy for village and local domain temples.

This evidence suggests a historical process whereby land as a material resource always remained under the control of relatively small units of social organisation. In addition, as I have argued earlier, there has been a longstanding principle of 
allowing or even encouraging the alienation of material resources for the sake of gaining symbolic resources, namely in the course of accommodating immigrants and newcomers into a house, village or domain. Indeed, even the more regular mode of banua expansion, through a process of emigration, is posited quite explicitly on a granting of material autonomy to branch villages while the source village retains a privileged access to symbolic resources. In short, the apparent tendency towards a gradual devolution of material resource control to smaller, subsidiary social units is in fact the result of the growth of originally small units of ritual organisation, such as single villages, into larger units, which are concerned increasingly with the distribution and control of symbolic resources rather than land usage rights or other material resources.

The ritual process of a gradual post-humanisation or deification of ancestral founders follows a similar logical pattern, in that gains in spiritual status are accompanied by the loss of material bodies, in successive layers of decreasing density (from kasar to halus). One possible explanation for this historical process of ritual alliance-building might be that alternative coercive means, which would have allowed for a similar expansion of the social order by an accumulation of material power, were never available to any group within Bali Aga society, which has been politically marginal as a whole for centuries.

Within a village, to control symbolic resources means to have ritual status as well as political authority. The people of the trunk who man the village council are not only the ritual leaders, they make and amend local customary regulations, settle disputes, impose sanctions and take political decisions on behalf of the community as a whole. In a domain, by contrast, the source village does not wield any such power in relation to branch villages outside the context of the annual ritual of the domain temple and perhaps in a number of other ritual matters. There is a political link between desa and banua, however, insofar as any claim to village founder status and associated rights is a local historical claim embedded in a wider domain history. The banua as a whole may be said to have a political dimension as well, but the orientation of this politics is toward participants' relationships with the outside world rather than an internal politics of land rights. Ritual domains have served as a powerful means for organising Bali Aga responses to a wider world beyond the highlands, a world that, I believe, would have long swallowed them up if it had not been for their intricate ritual networks of regional integration and cooperation. 10

I would now like to retell the origin narrative of a particular banua in order to illustrate that local participants themselves also reflect on this shift in significance in historically expanding place-based social categories, as they are transformed from material into symbolic resource pools. The example I have chosen is a narrative that describes how the village of Tebenan is transformed into the depopulated ritual centre of a sub-domain. 
Once a group of subjects approached the king of Bali at his residence near the ancient regional temple of Penulisan to ask leave for establishing a new settlement 'downhill' or teben. He granted their request for land, but also warned that disaster was sure to befall them if their village council were to grow beyond a membership of 33 household heads. The new village was called Tebenan to commemorate its origin from upstream Penulisan. Its rice fields were fertile, people's lives were leisurely, and soon the population grew until the village council had a membership of 200 heads of households. It then happened that a ritual was planned in which a deer was to be sacrificed, offered to the gods, and divided among the council members. But much of the forest had been cleared and deer were hard to find. On the day of the ritual, the hunting party finally returned with a small animal. Once the victim had been sacrificed and divided, the meat portions obtained were fewer than the number of eligible members. Arguments began, a fight broke out, even brothers killed one another, and the survivors were scattered in the eight directions of the compass as leaves blown by a wind. They founded eight new villages: Ulian, Gunung Bau, Bunutin, Langahan, Pausan, Bukhi, Bayung Cerik and Manikliyu, closest to the old Tebenan. The land was plentiful, but their lives were short, their labour hard and fruitless. Then the senior priest-leader (kubayan) of Manikliyu had a dream in which he learned that their lot would improve if only they remembered their common origin and resumed the cult of the village temple of the abandoned Tebenan. He enticed people to search for the foundations of the forgotten temple in the forest, and they uncovered nine [i.e., eight around a centre] sacred xylophone 'leaves' (don selunding), indicating that they had found the precise site of the old temple. The former village temple was then rebuilt to become a sub-regional temple. Ever since, the banua of eight villages has gathered there for an annual joint ceremony to honour their deified ancestors and to ask for a blessing upon their crops. Until today there may not be more than 33 elders in the 'village council' of Manikliyu. Before these elders take their ritual meal after a new moon meeting, they speak these words: 'King's men, insiders, elders of the heart, shoulder, elbow ... [and so forth in order of rank]. Come together, there are more food portions than people!'

The present origin narrative confirms Desa Manikliyu's role as a ritual leader among the eight villages of this sub-domain. The origin point of the sub-domain is identified as Pura Tebenan. The reference to the higher authority of the ancient kings of Penulisan, as the ultimate and now deified overlords of the land, reflects the fact that all villages in this sub-banua also participate within the larger ritual order around Pura Penulisan. 
When their usage in specific social contexts is taken into consideration it becomes evident that the origin narratives of a domain cannot be interpreted as disembodied texts. A structural analysis might reveal their intrinsic logic and the pattern of relations between their conceptual constituents, but even these elements have a contingent or non-intrinsic meaning. As Paul Ricoeur (1981: 217) has argued, narratives of origin bear reference to a cultural world per se but also to particular situations within that world.

Bali Aga origin narratives are rarely written down, they are not recited formally in ritual contexts, nor are they told in a ritual language marked by distinct formal characteristics. Most often origin narratives are retold spontaneously among a group of priests, elders and ordinary participants during the quieter moments of a festival at a banua temple. Their conversation can be described as a 'discussion' insofar as there is much room for polite disagreement about the narrative's content and interpretation. Therefore each narrative must be seen not as a monolithic text but as a tentative consensus reached by particular people at a particular time and place.

At the same time, such narratives also refer to a shared material world and a shared way of life, and thus contain non-ostensive references that bear meaning beyond any of the specific contexts in which the narrative might be retold and discussed. I agree with Ricoeur that origin narratives are not only the focus of a conflict of interpretations but may also depict important existential conflicts or 'boundary situations' in the world, which are of general relevance. A compromise approach towards the interpretation of myths of origin may thus be: to hear them, as the spoken discourse of specific authors with specific intentions, and simultaneously to read them, as the textual testimony of a collective world of shared experience and knowledge.

The tale of Pura Tebenan, if it is read rather than heard, illustrates how the social unity of a domain is contingent on the symbolic labour of recollecting and re-enacting a common origin. The path of origin is marked first by a lateral expansion, by the growth of a new branch domain out of the unity of the Penulisan domain. Then a second expansion is caused by the violent rupture of the village unity represented by what is now the Tebenan sub-domain temple. Processes of lateral expansion or sudden fission establish relationships between parts and a whole embodied as a sacred origin point. With each progressive differentiation, the degree of 'social unity' is diminished in the more immediate sense because the people involved no longer share the same, finite material resources of a single village. The idea of a social unity, however, is reintroduced simultaneously at a broader, more symbolic level by bringing several villages together in the ritual context of the origin temple and its ceremonial order.

The idea that only a finite number of people can derive a reasonable share from a single sacrifice may be taken as a metaphor, suggesting that in any given 
place there is a natural limit for sustainable solidarity on a material plane. This limit is often violated. The narrative hints at a golden mean, to be achieved by avoiding a practical condition of scarcity that arises from the togetherness of too many people in one place, and an equally undesirable condition of social isolation, which would arise if one were to define the small world of a single village as the only relevant sphere of social interaction. The problem of negotiating this balance is the archetypal 'boundary situation' in the world, which this origin narrative addresses. The proposed solution is to allocate material and symbolic concerns to separately conceived levels of social interaction. Thus, the narrative can be read as a culture-specific commentary on a general dilemma of social cooperation and competition in agrarian communities with finite land and expanding populations. It also illustrates some of the historical processes involved in the evolution of larger, regional social institutions, which in turn may have facilitated the emergence of small states (negara) in South-East Asia and in other parts of the Austronesian world.

\section{Concluding Remarks}

The highlands of Bali are divided into banua or ritual domains. These domains are spatially bounded alliances of several or even dozens of villages around a ceremonial centre in the oldest or source village, which signifies their common point of origin. Banua are said to have been established as emigrants from the source village or immigrants from elsewhere founded new settlements within its existing territories. Participating in the ceremonial life of village and domain temples, in the cult of the guardian spirits of the land, was and to some extent still is a way to assert the right to use that land. It is also much more. Domains, and the villages and houses within them, are not just stretches of usable land to people, they are sacred places of meaning. Temples are the markers of such sacred places and help to map complex identities arising from a complex history of migration.

The more distant events in this history, especially, are no longer concerned with the assertion of land rights but with the distribution of non-material resources within regional symbolic economies. The banua, from a historical perspective, is situated well beyond the boundary condition where material resource scarcity began to outweigh the benefits of practical cooperation. Banua temples are the spatial markers of the most distant events in origin history, the abode of the most completely disembodied or post-humanised beings, and the social stage on which struggles for the most refined, symbolic resources become the paramount theme.

I should add here that participants' personal concern with spiritual obligation is a powerful motivation independent of their concerns about relative status. People have a very immediate and highly personal bond to the ancestral land that keeps them physically alive, and to the history inscribed on it, the ritual 
path of origin that one day will lead them also to a post-human state of immortality. They also very much enjoy their participation in the larger ritual community of a domain. For the time being, these sentiments and associated local regulations have helped to preserve people's spiritual relationship to their land despite significant changes to the official, legal conceptualisation of land ownership that has occurred in Indonesia under Dutch rule and in the course of a number of land reforms since independence.

\section{References}

Ardika, Wayan and Peter Bellwood. 1991. 'Sembiran: The Beginnings of Indian Contact with Bali.' Antiquity, 65 (247). Pp.221-32.

Bernet-Kempers, A.J. 1991. Monumental Bali: Introduction to Balinese Archaeology. Berkeley: Periplus Editions.

Geertz, Clifford 1980. Negara: The Theatre State in Nineteenth-Century Bali. Princeton (N.J.): Princeton University Press.

Howe, Leo 2001. Hinduism \& Hierarchy in Bali. Oxford: James Currey.

Ramstedt, Martin. 1997. Weltbild, Heilsprakmatik und Herrschaftslegitimation im vorkolonialen Bali. Frankfurt: Peter Lang Verlag.

Reuter, Thomas A. 1998. 'The Banua of Pura Pucak Penulisan: A Ritual Domain in the Highlands of Bali.' Review of Indonesian and Malaysian Affairs, 32 (1).pp.55-109.

Reuter, Thomas A. 1999. 'People of the Mountains - People of the Sea: Negotiating the Local and the Foreign in Bali.' In L.H. Connor and R. Rubinstein (eds), Staying Local in the Global Village: Bali in the Twentieth Century, Honolulu: University of Hawai'i Press.

Reuter, Thomas A. 2002a. Custodians of the Sacred Mountains. Honolulu: University of Hawai'i Press.

Reuter, Thomas A. 2002b. The House of Our Ancestors: Precedence and Dualism in the Highlands of Bali. Leiden: KITLV Press.

Reuter, Thomas A. 2003. 'Mythical Centres'. In T.A. Reuter (ed.), Inequality, Crisis and Social Change in Indonesia: The Muted Worlds of Bali, London: Routledge-Curzon Press.

Ricoeur, Paul. 1981. 'The Model of the Text: Meaningful Action Considered as a Text.' In J.B. Thompson (ed.), Paul Ricoeur: Hermeneutics and the Human Sciences, Cambridge: Cambridge University Press.

Waelty, Samuel. 1993. 'Gemeinschaftsland und Aeltestenraete in den Bali Aga Gemeinden von Kintamani.' Geographica Helvetica, 1993 (1). pp.19-26. 


\section{ENDNOTES}

1 One could argue generally that in political institutions a concern with symbolic resources combines with a concern for material resources, such as having the technical means to exercise coercive force or surveillance, and that both forms of resources are needed in order to generate political power. The banua of highland Bali are not political institutions, however, except insofar as they create a degree of protective solidarity among the Bali Aga in relation to external threats (Reuter 2002a). Most likely these domains were de-politicised after the fall of highland kingdoms in the 14th century because the new kings in the southern lowlands would not tolerate a highland kingdom nor did they ever have the reach fully to incorporate and control the highlands. These kingdoms, while they did make use of military forces to sort out issues of competition among themselves, were also heavily reliant on the symbolic resource of ritual status as an underpinning of royal authority so as to stop dissent within the kingdom. This symbolic resource was generated either by way of the king's own involvement in ritual or by his patronage of Brahmana priests as ritual specialists (Geertz 1980; Ramstedt 1997). Similar observations could be made about small polities on other islands in the region.

${ }^{2}$ I am not denying that Hinduism has had a levelling influence on Bali and on the cultures of South-East Asia in general, however, there has not been any systematic campaign against local religious diversity in Bali until recently. Brahmana-dominated government Hindu organisations like Parisada Hindu Darma Indonesia have had a strong vested interest in standardizing the practice of Hinduism in Bali since Indonesian independence (Howe 2001). This agenda was largely a response to the pressures on Hindus to develop a standard code of belief and worship and some form of monotheism in order to gain recognition for Hinduism as a State-endorsed religion under the Indonesian Constitution, alongside Islam and Christianity.

3 Hindu kingdoms, of course, have long ceased to be bona fide political institutions in modern Bali, and the historical process of traditional state formation no longer applies. Nevertheless, this change is relatively recent. Many of Bali's kings had survived colonialism as regents under Dutch indirect-rule policy, and some of their descendents still command considerable influence and wealth. MacRae's paper (this volume) further shows that traditional forms of power arising at the ritual domain-'kingdom' interface are still relevant in Bali today.

${ }^{4}$ For example, while there is an overlap between the domain of Pura Pucak Penulisan and that of Pura Balingkang, the reason is that the two were still one single domain until quite recently, and are still connected through ritual interactions. The domain of Pura Pucak Indrakila and the network of Pura Batur were also previously part of the domain of Pura Penulisan, whose supreme prominence probably derives from the fact that it was a major state temple for Bali's early Hindu dynasties.

5 Note that the (branch) villages' temples are themselves origin sites and ritual centres in relation to the numerous houses or extended house groups that make up a village. The relationship between umah and desa could therefore be considered as an additional layer in an overall pattern of territorial organisation.

6 Networks of more exclusive or kinship-oriented temples are few and not very well formed in this part of Bali. These essentially inter-local networks seem to be more or less a southern Balinese innovation, which spread from aristocratic circles to commoners and has found its way into the highlands only in very recent times. Note the use of botanic metaphors to express the notion of origin and precedence.

7 The word ayahan is the noun form of Balinese ngayah, to work. This refers to the right of working a piece of communally owned land and the duty to perform a substantial amount of ritual labour in the context of village temple festivals, as well as paying a share of the ritual expenses incurred. Note that 'owned land' often refers to forested land that was cleared by newcomers who did not receive village land.

8 Botanic and body metaphors are used prolifically by the Bali Aga in reference to village councils, banua and many other aspects of their social organisation.

9 In villages where all land is privately owned, the distinction between founders and newcomers is maintained simply by forbidding the sons of newcomers to join the village council. In a way, newcomers are kept out even more systematically in these communities because land ownership as such is not enough to be a full citizen of the village. In other villages, newcomers gained entry into the council because they were given a plot of classificatory 'village land'. In some cases, tanah milik owners also became integrated. In those cases the distinction between the two types of land was eventually ignored to allow a recruitment of new village members, which reduced the cost of temple rituals per household. There is some historical evidence to suggest that such open recruitment tended to follow sudden population losses caused by a short-term famine or an epidemic. 


\section{Sharing the Earth, Dividing the Land}

10 An argument could be made that the ritual order of the banua is more specifically religious and less political in its character than the desa. It is difficult to say, however, whether this is yet another manifestation of a principle whereby larger social categories become concerned with more and more 'refined' (more exclusively symbolic) types of resources. It could well be that the lack of a stronger political dimension in the banua is simply the result of a wider Balinese political scenario in which the highlands were unable to establish a more highly developed form of political unity. 